\title{
Will environmental changes reinforce the impact of global warming on the prairie- forest border of central North America?
}

\author{
Lee E Frelich* and Peter B Reich
}

Within the next 50-100 years, the warming climate will have major effects on boreal and northern hardwood forests situated near the prairie-forest border of central North America. This biome boundary shifted to the northeast during past episodes of global warming, and is expected to do so again. The climate of the future will likely lead to higher mortality among mature trees, because of the greater frequency of droughts, fires, forest-leveling windstorms, and outbreaks of native and exotic insect pests and diseases. In addition, increasing populations of native deer and European earthworm invasions will inhibit the establishment of tree seedlings. The expected net impact of these factors will be a "savannification" of the forest, owing to the loss of adult trees at a rate faster than that at which they can be replaced. This will cause a greater magnitude and more rapid northeastward shift of the prairie-forest border, as compared with a shift solely attributable to the direct effects of temperature change.

Front Ecol Environ 2010; 8(7): 371-378, doi:10.1890/080191 (published online 4 Sep 2009)

$\mathrm{C}$ ontinental interiors have biome boundaries that are highly sensitive to climate change. The northern prairie-forest biome border in central North America is such a case; it is $\sim 2700 \mathrm{~km}$ in length, extending from northern Alberta, Canada, southeastward across the Canadian prairie provinces, and into the western Great Lakes region of the US (DeFries et al. 2000; Figure 1). Positioned more or less perpendicular to the border is a steep gradient from a prairie climate - featuring frequent droughts, summer heat waves, and a historically high fire frequency - to a forest climate, with rainfall evenly distributed throughout the year and cool summers (Changnon et al. 2002).

Although woody expansion into North American grasslands has been documented in the past (Samson and Knopf

\section{In a nutshell:}

- Global warming is expected to cause the existing prairie-forest border of central North America to shift to the northeast; a substantial area of currently forested lands will change to savannas or grasslands

- More frequent droughts, fires, and windstorms - in addition to increased incidence of exotic tree diseases/pests and population growth of native insects, native deer, and non-native earthworms - will reinforce the impacts of warmer temperatures on existing forests

- Society will face important decisions regarding forest management; namely, whether to resist or facilitate change and how to manage the new boundary areas in light of invasive species and climate change

Department of Forest Resources, University of Minnesota, St Paul, MN*(freli001@umn.edu)

Beyond the Frontier: Listen to Lee Frelich discussing this research on Frontiers' monthly podcast, at www.frontiersinecology.org.
1994), it is widely expected that, under a scenario of humaninduced global warming, the prairie biome will shift to the northeast and displace existing forests. The paleoecological record shows that this pattern of biome change occurred during previous climate-warming episodes; during the midHolocene warm period 7500 years before present (ybp), for example, a warmer climate and interactions between climate and fire frequency allowed grassland to replace boreal forests (dominated by jack pine [Pinus banksiana], black spruce [Picea mariana], balsam fir [Abies balsamea], aspen [Populus tremuloides], and paper birch [Betula papyrifera]) as well as hardwood forests (dominated by northern red oak [Quercus rubra], white oak [Quercus alba], sugar maple [Acer saccharum], American basswood [Tilia americana], and elm [Ulmus spp]; Camill and Clark 2000; Umbanhowar 2004). Future projections for a " $2 \times \mathrm{CO}_{2}$ " climate (ie 560 parts per million [ppm] atmospheric $\mathrm{CO}_{2}$, or twice the preindustrial concentration of $280 \mathrm{ppm}$ ) suggest a northeastward shift of biomes and tree ranges of 100-500 km (Lenihan and Neilson 1995; Walker et al. 2002), resulting in the potential loss of forests on 200000 to 1 million $\mathrm{km}^{2}$ of land in central North America. The upper estimate is more than twice the size of the state of California.

These projections, however, take into account only the climatic envelope within which certain tree species and biomes currently exist. Several other human-induced drivers of change will influence prairie-forest border dynamics, so that the types or magnitudes of future changes may differ from those in the paleoecological record, probably leading to no-analog plant communities (ie there is no past or current community of a similar composition; Williams and Jackson 2007). These drivers include invasive earthworms, tree diseases and pests, changes in dynamics of native insect populations, increasing deer 


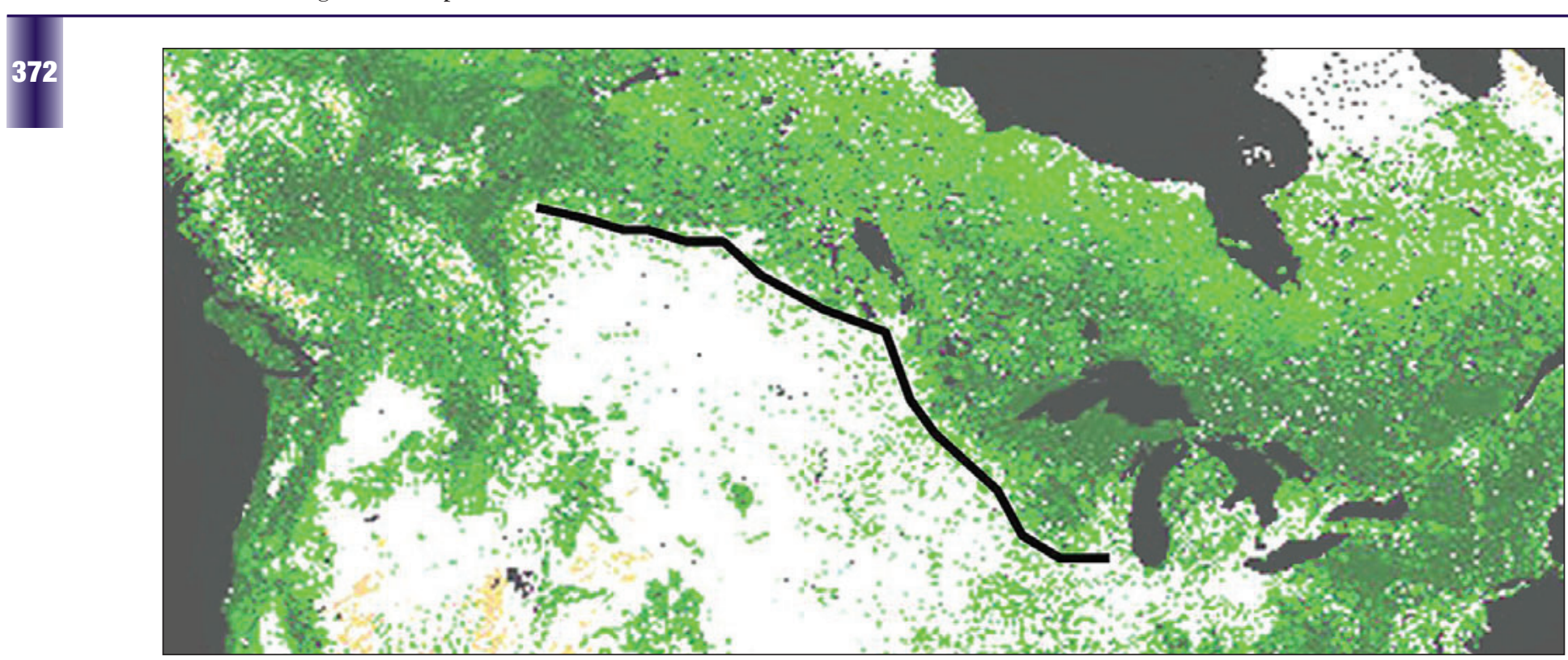

Figure 1. Prairie-forest border in central North America (thick black line). Forest cover shown in green, non-forest is white, and water is black. Modified from DeFries et al. (2000).

populations, changing disturbance type and frequency, increased plant growth due to higher availability of $\mathrm{CO}_{2}$ $\left(\mathrm{CO}_{2}\right.$ fertilization), and nitrogen deposition. All of these drivers are capable of causing ecosystem change individually, but their impacts will occur concurrently with the direct impacts of climate change. In some systems with multiple drivers, simultaneous changes in two or more of them might result in no net change, because various drivers may counteract one another. However, for the prairie-forest border of central North America, global warming will interact with these drivers of change by facilitating faster and greater impacts, which will in turn reinforce the impacts of warming itself. The objective of this paper is to review important drivers of change along the prairie-forest border in central North America and how their interactions with the warming climate may influence forests.

\section{Climate change and impacts on forests}

Given the anticipated degree of warming, the most important direct impact on forests will probably be drought. For the continued existence of a given forest, all else being equal, trees must survive the longest summer dry period that occurs at a multidecadal scale. A warmer, drier climate would have much greater consequences for the northern prairie-forest border of central North America than would a warmer, wetter climate, which would still support forests, although of different composition. The best available projections for central North America for summer (June, July, and August) temperatures by the late 21 st century are $+3-9^{\circ} \mathrm{C}$ (range between low and high $\mathrm{CO}_{2}$ emission scenarios established by the Intergovernmental Panel on Climate Change [IPCC]; Wuebbles and Hayhoe 2004; Christensen et al. 2007). Although long-term forecasts are uncertain, the most probable scenario for summer precipitation is that it will remain similar to that from $1970-1999$ or decline $10-30 \%$ by the end of the 21 st century; there is only a slight chance that it will increase (Wuebbles and Hayhoe 2004; Christensen et al. 2007). A negative change in the precipitation-to-evaporation ratio and drier summers are therefore thought to be the most probable scenario. This is consistent with observations in the region during the late 20th century, which show increases in temperature twice that of the global mean temperature rise and greater temporal variability in precipitation, leading to more droughts, shorter winters, and longer growing seasons ( $\mathrm{M}$ Seeley pers comm).

The projected change toward lower precipitation-toevaporation ratios and higher temperatures drives climateenvelope predictions that major tree species will shift their ranges northward by up to $500 \mathrm{~km}$ in central North America (Prasad et al. 2008). This is consistent with northward range shifts observed during episodes of Holocene warming that were similar in magnitude to those predicted for the 21st century, although the rate of change during the 21st century may be an order of magnitude faster than that of mid-Holocene warming, possibly outstripping the ability of tree species to keep pace with climate change (Davis and Shaw 2001).

Several simulations of modern and future biome boundaries show substantial differences (eg Lenihan and Neilson 1995; Notaro et al. 2007). However, they all suggest that large-magnitude northward shifts of biome boundaries are likely to occur at mid-continental, mid-to-high latitude regions, such as the central North American prairie-forest border and the interior forests of Siberia.

Foresters have reported dieback of mature tree crowns and regeneration failures throughout the northern hardwood forest region in Minnesota, Wisconsin, and Michigan in recent years (USDA 2008; Figure 2), although the underlying mechanisms remain unclear. 
Increasing drought frequency, in combination with shallow soils, soils poor in base cations, and secondary impacts of insects, have led to sugar maple dieback in the past (Auclair et al. 1996). Warmer and longer growing seasons have also contributed to dieback of paper birch (Jones et al. 1993).

Warming climates generally do not follow a smooth upward trajectory. Forests will experience runs of several unusually warm years, with temperatures equal to predicted mean temperatures a few decades in the future, thus hastening the rate of forest change (Cohen and Pastor 1991). The paleoecological record shows that changes in the location of the prairie-forest border and in tree species distribution have occurred within a few decades in response to periods of drought and resulting stress (Camill and Clark 2000; Foster et al. 2006).

In summary, multiple lines of evidence - including recent climate trends, recent observations of forest response to episodes of warm and dry climate, future projections of climate, future projections of tree species ranges, and the best available predictions for future biome boundaries - indicate that a warmer climate will be less favorable for the continued existence of forests near the current prairie-forest border. This conclusion is reinforced by the paleoecological record of changes that occurred during previous periods of warming climate.

\section{Indirect impacts of climate change}

\section{Changing disturbance regimes}

Stand-killing disturbances, such as fire and wind, can give tree species adapted to a warmer climate a chance to replace existing species (Overpeck et al. 1990). Fire has been an important factor influencing the location of the prairie-forest border, and decreases in fire frequency due to land use, fragmentation, and fire suppression (coupled with several relatively moist decades) have led to the expansion of woody species into the prairie biome over the past 50 years (Samson and Knopf 1994). Thus, changes in fire frequency due to climate warming are likely to have important impacts throughout the prairie-forest region. Although climate warming will create conditions more conducive to increased fire frequency and severity at any given level of landscape fragmentation, other factors may result in divergent fire regimes close to and distant from the prairie-forest ecotone. For instance, land-use patterns in the geographic zone at the interface between the forest and prairie bio-

mes, coupled with active fire suppression, will result in lower frequency and greater severity of forest fires. This is because much of that landscape is agricultural and unlikely to burn, and the generally high levels of fragmentation in the area will reduce fire spread. Although fragmentation has positive (more human access for ignition) and negative (more fire breaks) effects on fire frequency, the latter will dominate in areas with mixed land types and land uses, reducing the impacts climate change might otherwise have on fire incidence and spread.

In contrast, in densely forested areas with little fragmentation - such as conifer forests several tens of kilometers away from the prairie-forest interface, but still within the area that will experience a substantially warmer and drier climate - fires may become more frequent and more severe. This would include large tracts of boreal forest in Canada and the northern lake states of the US, where fire frequency is predicted to increase with global warming (Flannigan et al. 2001). A variety of vegetation types found to the south of the prairie-forest border, including prairie, aspen parkland, pine savanna, and oak savanna, could expand into currently forested areas (Curtis 1959; Young et al. 2006). These new vegetation types would also support more frequent fires than would closedcanopy forests, thus reinforcing their persistence.

Wind storms are also important factors in forest development. Severe thunderstorms, known as derechos, are capable of producing forest-leveling winds across millions of hectares (Rich et al. 2007). The highest frequency of these storms occurs within the "derecho triangle", which - with vertices in western Pennsylvania, north-central Texas, and central Minnesota - includes the traditional "tornado alley" of central North America, as well as the prairie biome to the southwest. Derechos require warm and humid summer days, meteorological conditions that are expected 

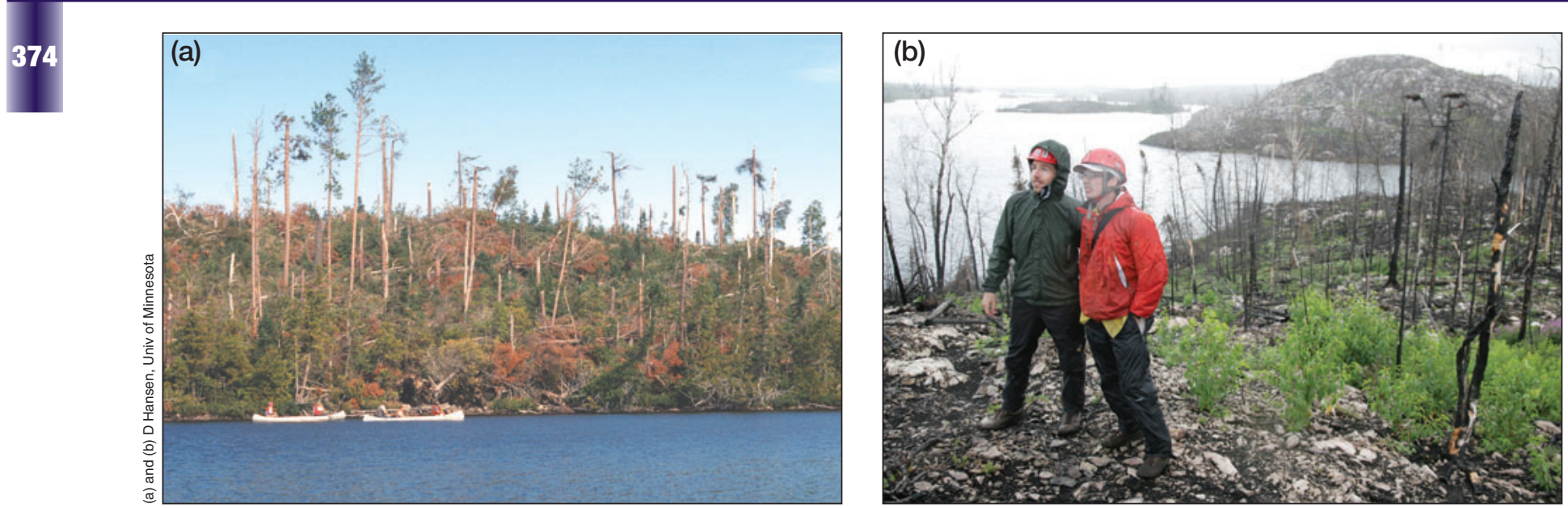

Figure 3. Major disturbance events will be more common with global warming and transform the composition of large tracts of forest. (a) Unlogged, 200-year-old boreal forest with upper canopy destroyed by the derecho of 4 July 1999, Boundary Waters Canoe Area Wilderness, Minnesota. (b) The same forest as in (a), one year after the exceptionally severe Cavity Lake Fire of 2006, illustrating the combined impact of severe wind and fire disturbance.

to occur more often in this region with climate warming (Trapp et al. 2007). Currently, the frequency of derechos in the prairie biome is 5-20 times that in the interior of the forest biome (Coniglio and Stensrud 2004), and a northeastward shift in climatic conditions could bring large increases in derecho frequency to the forest biome.

These windstorms are capable of transforming the species composition of vast swaths of forest $(>200 \mathrm{~km}$ in length) within a day, because certain tree species have a higher risk of blowing down than others (Rich et al. 2007; Figure 3). These storms also present an opportunity for understory species adapted to a warmer climate to increase their dominance through regeneration. In addition, the alteration in fuel structure created by blowndown trees greatly increases the chances of severe fires (Figure 3), even in hardwood and hemlock forests that did not formerly experience such events. These very severe fires could convert the forest to early successional aspen and birch (Frelich and Reich 1999), or give species adapted to a warmer climate a chance to invade.

\section{Insects and diseases}

Many exotic insects and diseases that affect trees have arrived at, or are approaching, the prairie-forest border. Survival of insects and disease organisms is generally greater when winters are less severe, and their populations can increase faster with higher survival and longer breeding seasons, leading to greater rates of spread (Logan et al. 2003). Dutch elm disease (Ophiostoma ulmi and Ophiostoma novo-ulmi), hemlock wooly adelgid (Adelges tsugae), and emerald ash borer (Agrilus planipennis) are either present at, or moving toward, the prairie-forest border and threaten seven species of native trees. The adelgid is limited by the cold winters of the current climate (Evans and Gregoire 2007), but it could survive winters in the area under the IPCC low emissions climate scenarios. Asian long-horned beetle (Anoplophora glabripennis), although so far confined to urban areas, has the potential to greatly diminish the genera Populus (four species present) and Acer (four species present, including the ecologically and commercially important sugar maple, A saccharum). Sudden oak death (caused by the fungus Phytopthora ramorum) has the potential to reduce abundance of two oak species; currently, Phytopthora is not thought to be capable of surviving near the prairie-forest border, because of the cold climate (Smith and Coulston 2002), but that could change in the future.

Native insect pests (including species from elsewhere in North America) are also expected to play a major role in forest change in a warming climate. Insect populations that may have been in dynamic equilibrium with forests while the climate was relatively cool can experience outbreaks when longer growing seasons and milder winters facilitate reproduction and survival. For example, mountain pine beetles (Dendroctonus ponderosae), native to British Columbia, Canada, have killed 12 million ha of lodgepole pine (Pinus contorta) forest in that province in recent years; the large extent of the outbreak is partly attributable to a warmer, more favorable climate for the insects, especially in winter (Taylor et al. 2007). With warmer winters, the mountain pine beetle has the potential to cause major mortality in jack pine-dominated forests along the southern margin of the boreal forest across the continent (Logan 2007).

\section{Exotic earthworms}

European earthworms, principally the nightcrawler (Lumbricus terrestris), leaf worm (Lumbricus rubellus), and angleworms (Aporrectodea spp), are invading forests along the entire prairie-forest border, including boreal forests from Alberta to northern Minnesota, and hardwood forests from Minnesota to Indiana (Frelich et al. 2006; Cameron et al. 2007). The northern part of the prairie-forest border, from northern Wisconsin through Alberta, has no native earthworms. Earthworm invasions 

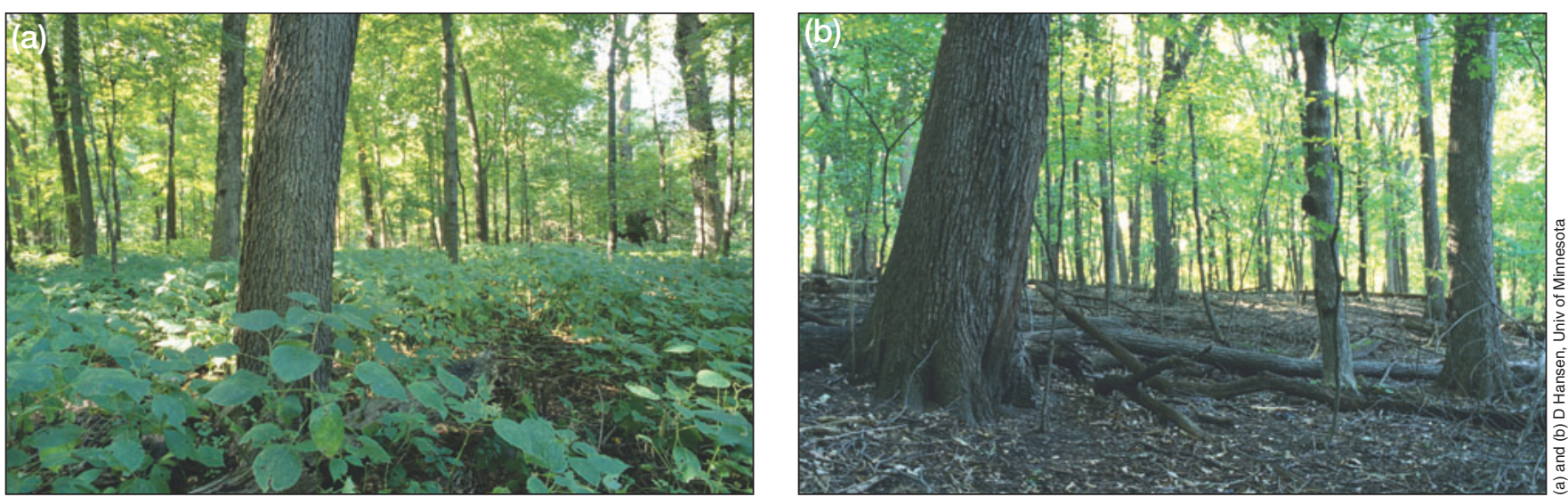

Figure 4. Forest change caused by earthworm invasion and deer grazing. (a) Intact forest of sugar maple, basswood, and red oak. (b) Forest with high deer population and earthworm invasion. Note the absence of tree seedlings, herbs, and duff on the forest floor.

have been linked to dieback and reproductive failure in mature northern hardwood trees, and loss of native plant species richness through a cascade of ecological effects (Holdsworth et al. 2007). These include raising soil bulk density, decreasing availability of nitrogen $(\mathrm{N})$ and phosphorus by $20-40 \%$, and removing the organic horizon (ie the leaf litter or duff), leaving the forest floor without the insulating and moisture-holding capacities of the previously thick litter layer (Hale et al. 2005; Figure 4). The tree species most impacted is sugar maple.

\section{Deer overabundance}

White-tailed deer (Odocoileus virginianus) have been an important factor negatively impacting survival and recruitment of trees in central and eastern North America (Coté et al. 2004; Figure 4). Deer browse woody plants during the winter, when herbs are unavailable, and prefer seedlings of certain species of trees: northern white cedar (Thuja occidentalis), yellow birch (Betula alleghaniensis), northern red oak, eastern hemlock (Tsuga canadensis), and, in some areas, white pine (Pinus strobus). Reproduction of these species has been nearly eliminated in large tracts of forest within $500 \mathrm{~km}$ of the prairie-forest border (Cornett et al. 2000; Rooney et al. 2000). Deer populations in the boreal forest along the northwestern segment of the prairie-forest border are currently low, but are expected to increase as winters become milder, since winter mortality has been a historically limiting factor (Fieberg et al. 2008). Increasing acreage of aspen forest and fragmentation as logging proceeds into the boreal forest also favor expansion of deer populations (Alverson et al. 1988).

\section{$\mathrm{CO}_{2}$ fertilization and nitrogen deposition}

Projected increases in atmospheric $\mathrm{CO}_{2}$ concentrations and in $\mathrm{N}$ deposition may counteract some impacts of climate change by enhancing forest productivity and drought resistance. Enhanced productivity due to $\mathrm{CO}_{2}$ fertilization and reduced water stress may occur in forests of the prairie-forest border region (Reich et al. 2006). The latter is more relevant to a consideration of possible climate-change interactions in this region. The ubiquitous water savings under elevated $\mathrm{CO}_{2}$ are achieved via reduced stomatal conductance (Ainsworth and Long 2005) and can result in heightened seedling establishment (Davis et al. 2007). However, this should be offset to some extent by modest increases in leaf area index (projected green leaf area per unit ground area) under elevated $\mathrm{CO}_{2}$ (Ainsworth and Long 2005; Reich et al. 2006), such that soil moisture patterns will be only modestly enhanced in most situations. Elevated $\mathrm{CO}_{2}$ levels will constrain the rise in evapotranspiration under warmer (and especially warmer and drier) conditions to some extent, and will therefore partially counteract the effects of warming on plant and soil moisture relations. Given evidence from the free-air $\mathrm{CO}_{2}$ enrichment literature, it is likely that these effects will be modest (Ainsworth and Long 2005; Reich et al. 2006).

Much of the northern hardwood and southern boreal forest near the prairie-forest border receives low-to-intermediate levels of $\mathrm{N}$ deposition (Keene et al. 2002). Given that these systems are known to be N-limited in terms of productivity (Reich et al. 1997, 2001), the continuing $\mathrm{N}$ additions will result in a modest average increase in productivity (Magill et al. 2004). Deciduous hardwoods should gain some advantage in comparison with prairie species under heightened $\mathrm{N}$ deposition levels, because the relative competitiveness of deciduous trees versus grasses increases with increasing $\mathrm{N}$ supply (Köchy and Wilson 2001). Furthermore, feedback effects of deciduous trees on $\mathrm{N}$ cycling will lead to conditions that are more conducive to trees than grasses (Reich et al. 2001; Dijkstra et al. 2006), possibly amplifying any influence of $\mathrm{N}$ deposition on tree-grass competitive interactions.

It seems probable that the effects of higher $\mathrm{CO}_{2}$ concentrations will partially offset the impacts of future droughts, and that $\mathrm{N}$-deposition effects will partially offset the impacts of earthworm invasion on nutrient availability. However, these two factors will not reduce the 


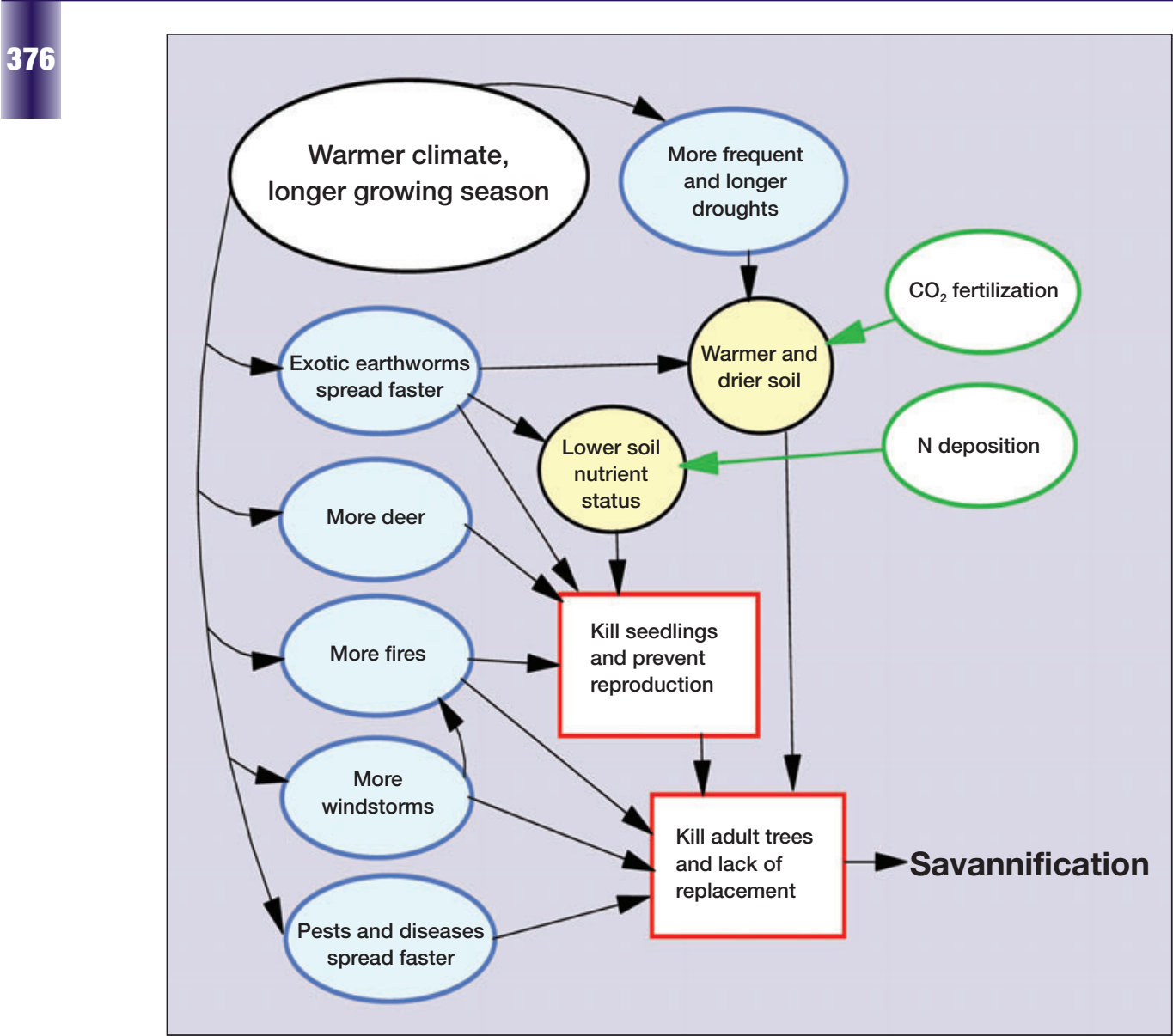

Figure 5. Interactions between global warming and other drivers of change affecting the prairie-forest border of central North America, and their impact on trees. Blue ovals represent drivers with potential negative impacts on trees that are likely to be enhanced by a warmer climate. Yellow circles represent basic resources that may be changed by a warmer climate or by its interactions with other drivers. Green ovals represent drivers that may counteract negative impacts on trees to some extent. Red rectangles show the results of drivers on trees and their reproduction.

negative impacts that storms, fires, exotic insects and diseases, and deer grazing have on forests.

\section{Cumulative impacts of multiple drivers}

Cumulative negative impacts of all drivers of change on trees in the prairie-forest border region may be quite large (Figure 5). Storms, fires, invasive insects, and unsuitable climate will remove mature forests from the landscape, while other factors, such as deer and European earthworms, will prevent tree reproduction. The loss of mature trees will also contribute to lack of reproduction through reduction in propagule availability. The net result for forests within a few hundred kilometers of the prairie-forest border is that tree mortality will increase and regeneration may not be able to keep pace.

Most genera and species of trees present along the prairie-forest border are sensitive to at least one potential negative impact. Fir, spruce, and larch will not find a warmer climate suitable. Both invasive and native insects and diseases have the potential to remove or greatly reduce several genera, such as maple, ash, pine, aspen, oak, hemlock, and elm, from large swaths of forest close to the prairie-forest border. Deer populations will prevent reproduction of several species that would otherwise be resistant to the impacts of a warmer climate, including white pine, northern red oak, yellow birch, and northern white cedar. Even tree species that experience a positive impact from one driver may respond negatively to other factors. Hemlock provides a good example. Earthworms create a bare mineral soil seedbed, which is better for hemlock than thick litter. However, some researchers have predicted the extinction of hemlock due to the hemlock wooly adelgid; deer grazing has also been shown to have a widespread negative impact on hemlock regeneration (Rooney et al. 2000), and increased drought and fire frequency will negatively affect this species.

\section{Conclusions}

Climate warming is predicted to lead to savannification of the forest near the northern prairie-forest border. The cumulative impacts of droughts, storms, fires, insects and diseases, invasive species, and deer grazing may be partially offset by $\mathrm{CO}_{2}$ fertilization and $\mathrm{N}$ deposition. However, the net impact of all these drivers is expected to reinforce negative impacts of global warming, thereby hastening the decline of forests (Figure 5).

The relatively cool temperatures and frequent precipitation of the historic climate of the past several centuries, coupled with periodic crown fires for jack pine, have allowed boreal forest tree species, such as jack pine and black spruce, to exist from bogs to rocky hilltops, and northern hardwoods to spread across a soil gradient from clays to loamy sands. In a warmer climate, more differentiation among vegetation types is expected across soil types and slope positions (Pastor and Post 1988). Mesic forests are expected to narrow their niche, "abandoning" drier sites, and if the density of forested sites becomes low enough, people may perceive that the location of the prairie-forest border has shifted. Important decisions regarding forest management will need to be made as the climate warms: do we prioritize the maintenance of as much of our recent forest heritage as is possible? Do we let nature takes its (human-aided) course? Or do we proac- 
tively use adaptive management strategies to accelerate the shift toward new vegetation, better suited to the conditions of the late 21st century? The answers to these questions are not simple and effective management will probably include a combination of all three approaches, guided by input from a wide array of stakeholders, including citizens, the timber industry, and public and private land management agencies.

Tracts of forests close to the prairie-forest border - destined to become grassland or savanna as the climate warms, and currently designated as wilderness - may represent a restoration opportunity for native grasslands and savannas, most of which have been converted to agriculture during the previous century. Remnant grasslands and savannas must be preserved, to serve as a seed source for future expansion into forested areas, thus allowing forests to make a "graceful" transition to prairie and/or savanna. These future grasslands may be no-analog communities, but a no-analog community of native species is probably more desirable than a no-analog community composed of non-native species.

\section{Acknowledgements}

We thank the Wilderness Research Foundation; the National Science Foundation Long Term Ecological Research program; the Department of Energy Program for Ecosystem Research; and the University of Minnesota College of Food, Agricultural, and Natural Resources Sciences for financial support. We appreciate the assistance of S Barrott with the figures.

\section{References}

Ainsworth EA and Long SP. 2005. What have we learned from 15 years of free-air $\mathrm{CO}_{2}$ enrichment (FACE)? A meta-analytic review of the responses of photosynthesis, canopy properties, and plant production to rising $\mathrm{CO}_{2}$. New Phytol 165: 351-72.

Alverson WS, Waller DM, and Solheim SL. 1988. Forests too deer: edge effects in northern Wisconsin. Conserv Biol 2: 348-58.

Auclair AND, Lill JT, and Revenga C. 1996. The role of climate variability and global warming in the dieback of northern hardwoods. Water Air Soil Poll 91: 163-86.

Cameron EK, Bayne EM, and Claperton MJ. 2007. Human-facilitated invasion of exotic earthworms into northern boreal forests. Ecoscience 14: 482-90.

Camill P and Clark JS. 2000. Long-term perspectives on lagged ecosystem responses to climate change: permafrost in boreal peatlands and the grassland/woodland boundary. Ecosystems 3: 534-44.

Changnon SA, Kunkel KE, and Winstanley D. 2002. Climate factors that caused the unique tall grass prairie in the central United States. Phys Geogr 23: 259-80.

Christensen JH, Hewitson B, Busuioc A, et al. 2007. Regional climate projections. In: Solomon S, Qin D, Manning M, et al. (Eds). Climate change 2007: the physical science basis. Contribution to Working Group I to the Fourth Assessment Report of the Intergovernmental Panel on Climate Change. New York, NY: Cambridge University Press.

Cohen Y and Pastor J. 1991. The responses of a forest model to serial correlations of global warming. Ecology 72: 1161-65.

Coniglio MC and Stensrud DJ. 2004. Interpreting the climatology of derechos. Weather Forecast 19: 595-605.
Cornett MW, Frelich LE, Puettmann KJ, and Reich PB. 2000. Conservation implications of browsing by Odocoileus virginianus in remnant upland Thuja occidentalis forests. Biol Conserv 93: 359-69.

Cotè SD, Rooney TP, Tremblay J-P, et al. 2004. Ecological impacts of deer overabundance. Annu Rev Ecol Syst 35: 113-47.

Curtis JT. 1959. The vegetation of Wisconsin. Madison, WI: University of Wisconsin Press.

Davis MA, Reich PB, Knoll MBJ, et al. 2007. Elevated atmospheric $\mathrm{CO}_{2}$ : a nurse plant substitute for oak seedlings establishing in old fields. Glob Change Biol 13: 2308-16.

Davis MB and Shaw RG. 2001. Range shifts and adaptive responses to Quaternary climate change. Science 292: 673-79.

DeFries R, Hansen M, Townshend JRG, et al. 2000. A new global $1-\mathrm{km}$ data set of percent tree cover derived from remote sensing. Glob Change Biol 6: 247-54.

Dijkstra FS, Wrage K, Hobbie SE, and Reich PB. 2006. Tree patches show greater $\mathrm{N}$ losses but maintain higher soil $\mathrm{N}$ availability than grassland patches in a frequently burned oak savanna. Ecosystems 9: 441-52.

Evans AM and Gregoire TG. 2007. A geographically variable model of hemlock woolly adelgid spread. Biol Invasions 9: 369-82.

Fieberg J, Kuehn DW, and DelGiudice GD. 2008. Understanding variation in autumn migration of northern white-tailed deer by long-term study. J Mammal 89: 1529-39.

Flannigan M, Campbell I, Wotton M, et al. 2001. Future fire in Canada's boreal forest: paleoecology results and general circulation model-regional climate model simulations. Can J Forest Res 31: 854-64.

Foster DR, Oswald WW, Faison EK, et al. 2006. A climatic driver for abrupt mid-Holocene vegetation dynamics and the hemlock decline in New England. Ecology 87: 2959-66.

Frelich LE and Reich PB. 1999. Neighborhood effects, disturbance severity, and community stability in forests. Ecosystems 2: 151-66.

Frelich LE, Hale CM, Scheu S, et al. 2006. Earthworm invasion into previously earthworm-free temperate and boreal forests. Biol Invasions 8: 1235-45.

Hale CM, Frelich LE, Reich PB, and Pastor J. 2005. Effects of European earthworm invasion on soil characteristics in northern hardwood forests of Minnesota, USA. Ecosystems 8: 911-27.

Holdsworth AR, Frelich LE, and Reich PB. 2007. Effects of earthworm invasion on plant species richness in northern hardwood forests. Conserv Biol 21: 997-1008.

Jones EA, Reed DD, Mroz GD, et al. 1993. Climate stress as a precursor to forest decline: paper birch in northern Michigan, 1985-1990. Can J Forest Res 23: 229-33.

Keene WC, Mantag JA, Maben JR, et al. 2002. Organic nitrogen in precipitation over eastern North America. Atmos Environ 36: 4529-40.

Köchy M and Wilson SD. 2001. Nitrogen deposition and forest expansion in the northern Great Plains. J Ecol 89: 807-17.

Lenihan JM and Neilson RP. 1995. Canadian vegetation sensitivity to projected climatic change at three organizational levels. Climatic Change 30: 27-56.

Logan JA. 2007. Climate change induced invasions by native and exotic pests. In: Gottschalk K (Ed). Proceedings, 17th US Department of Agriculture interagency research forum on gypsy moth and other invasive species 2006. General Technical Report NRS-P-10. Newton Square, PA: USDA Forest Service, Northern Research Station.

Logan JA, Regniere J, and Powell JA. 2003. Assessing the impacts of global warming on forest pest dynamics. Front Ecol Environ 1: $130-37$.

Magill AH, Aber JD, Currie WS, et al. 2004. Ecosystem response to 15 years of chronic nitrogen additions at the Harvard Forest 
LTER, Massachusetts, USA. Forest Ecol Manag 196: 7-28.

Notaro M, Vavrus S, and Liu Z. 2007. Global vegetation and climate change due to future increases in $\mathrm{CO}_{2}$ as projected by a fully coupled model with dynamic vegetation. J Climate 20: 70-90.

Overpeck T, Rind D, and Goldberg R. 1990. Climate-induced changes in forest disturbance and vegetation. Nature 343: 51-53.

Pastor J and Post WM. 1988. Response of northern forests to $\mathrm{CO}_{2}$ induced climate change. Nature 334: 55-58.

Prasad AM, Iverson LR, Matthews S, and Peters M. 2008. Climate change tree atlas (a spatial database of 134 tree species of the eastern USA). www.nrs.fs.fed.us/atlas/tree/tree_atlas.html. Viewed 8 Oct 2008.

Reich PB, Grigal DF, Aber JD, and Gower ST. 1997. Nitrogen mineralization and productivity in 50 hardwood and conifer stands on diverse soils. Ecology 78: 335-47.

Reich PB, Hungate BA, and Luo Y. 2006. Carbon-nitrogen interactions in terrestrial ecosystems in response to rising atmospheric $\mathrm{CO}_{2}$. Annu Rev Ecol Evol S 37: 611-36.

Reich PB, Peterson DA, Wrage K, and Wedin D. 2001. Fire and vegetation effects on productivity and nitrogen cycling across a forest-grassland continuum. Ecology 82: 1703-19.

Rich RL, Frelich LE, and Reich PB. 2007. Wind-throw mortality in the southern boreal forest: effects of species, diameter and stand age. J Ecol 95: 1261-73.

Rooney TP, McCormick RJ, Solheim SL, and Waller DM. 2000. Regional variation in recruitment of hemlock seedlings and saplings in the upper Great Lakes, USA. Ecol Appl 10: 1119-32.

Samson FB and Knopf FL. 1994. Prairie conservation in North America. BioScience 44: 418-21.

Smith WD and Coulston JW. 2002. Preliminary SOD risk/hazard map. Arlington, VA: USDA Forest Service State and Private Forestry, FHP Research and Development Cooperative FHM Program.

Taylor SW, Carroll AL, Alfaro RI, and Safranyik L. 2007. Forest, climate and mountain pine beetle outbreak dynamics in Western Canada. In: Safranyik L and Wilson B (Eds). The mountain pine beetle: a synthesis of biology, management and impacts on lodgepole pine. Victoria, Canada: Canadian Forest Service.

Trapp RJ, Diffenbaugh NS, Brooks HE, et al. 2007. Changes in severe thunderstorm environment frequency during the 21 st century caused by anthropogenically enhanced global radiative forcing. P Natl Acad Sci USA 104: 19719-23.

Umbanhowar Jr CE. 2004. Interaction of fire, climate and vegetation change at a large landscape scale in the Bigwoods of Minnesota, USA. Holocene 14: 661-76.

USDA (US Department of Agriculture). 2008. Forest health monitoring program, aerial survey viewer. http://na.fs.fed.us/fhp/ ta/av/index.shtm. Viewed 24 Aug 2009.

Walker KV, Davis MB, and Sugita S. 2002. Climate change and shifts in potential tree species range limits in the Great Lakes Region. J Great Lakes Res 28: 555-67.

Williams JW and Jackson ST. 2007. Novel climates, no-analog communities, and ecological surprises. Front Ecol Environ 9: 475-82.

Wuebbles DJ and Hayhoe K. 2004. Climate change projections for the United States Midwest. Mitigation and Adaptation Strategies for Global Change 9: 335-63.

Young JE, Sánchez-Azofeifa A, Hannon SJ, and Chapman R. 2006. Trends in land cover change and isolation of protected areas at the interface of the southern boreal mixedwood and aspen parkland in Alberta, Canada. For Ecol Manag 230: 151-61.

\title{
(Pa Podcasts
}

\section{Have you visited the newly designed ESA podcast site?}

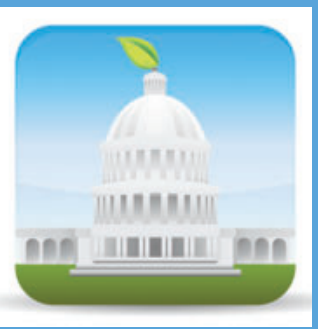

The Ecologist Goes to Washington showcases the stories of ecologists involved in public policy.

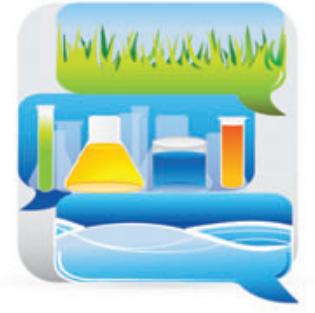

Field Talk tells the tales behind the science published in Ecology, Ecological Applications, and Ecological Monographs.

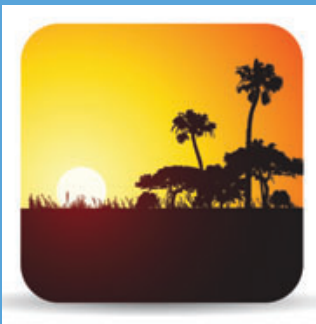

Beyond the Frontier features interviews regarding recent articles in Frontiers in Ecology and the Environment.

\section{Check out all the podcasts at}

\author{
www.esa.org/podcast
}

